\title{
Gastric epithelioid-cell granuloma in a paediatric patient with Crohn's disease
}

\author{
Kenji Tominaga, ${ }^{1}$ Mitsuru Kato, ${ }^{1}$ Kei Takahashi, ${ }^{2}$ Iruru Maetani ${ }^{1}$
}

${ }^{1}$ Division of Gastroenterology and Hepatology, Department of Internal Medicine, Toho University Ohashi Medical Center, Tokyo, Japan ${ }^{2}$ Department of Surgical Pathology, Toho University Ohashi Medical Center, Tokyo, Japan

\section{Correspondence to} Dr Kenji Tominaga, kenjitominaga@hotmail.com

\section{DESCRIPTION}

A youth in his later teenage years was referred to our hospital with erythema nodosum in his lower extremities. He had previously received surgical treatment for an anal fistula at another hospital. The patient presented with weight loss and fever but had no abdominal pain, diarrhoea, bloody stools, no upper gastrointestinal symptoms and a faecal culture was negative. Ileocolonoscopy revealed longitudinal ulcers in the terminal ileum and multiple erosions from caecum to rectum. Crohn's disease (CD) seemed the most likely cause and biopsy specimens demonstrated non-specific features of CD. Oesophagogastroduodenoscopy was performed in order to establish a diagnosis and to confirm the location and extent of the disease. Erosions were detected on the lesser curvature of the stomach body, the posterior wall of the stomach in the prepylorus region (figure 1) and on the duodenal bulb. A biopsy specimen from the prepylorus erosion identified an epithelioid-cell granuloma (figure 2), but focally enhanced gastritis was not detected. Helicobacter pylori infection was not present and non-steroidal anti-inflammatory drugs (NSAIDs) were not used. The biopsy specimens from the duodenal bulb erosions showed no focal cryptitis of the duodenum, which would indicate CD. ${ }^{1}$ Gastric erosion biopsies can be used to detect granulomas ${ }^{2}$ and may help in establishing a diagnosis of $\mathrm{CD}^{3}$ A general consensus is lacking regarding a definition of what qualifies as significant gastric involvement in CD. This case may support the inclusion of gastric erosions without

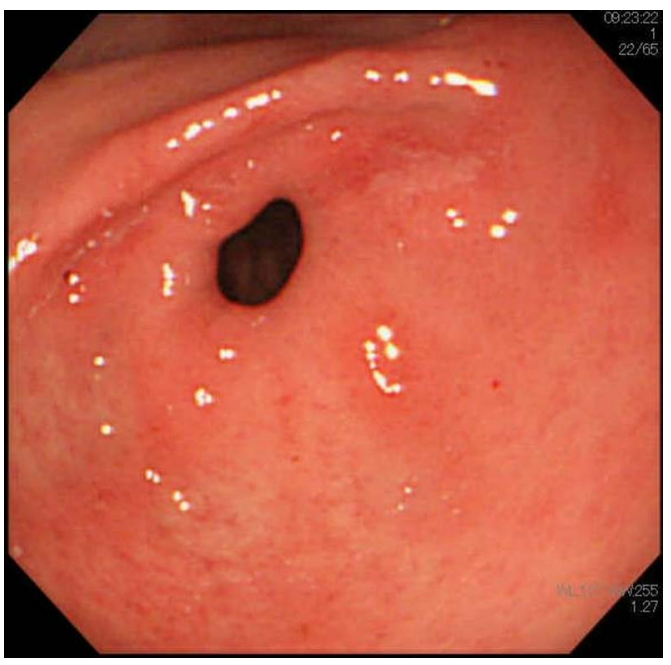

Figure 1 Oesophagogastroduodenoscopy revealed an erosion on the posterior wall of the stomach in the prepylorus region.

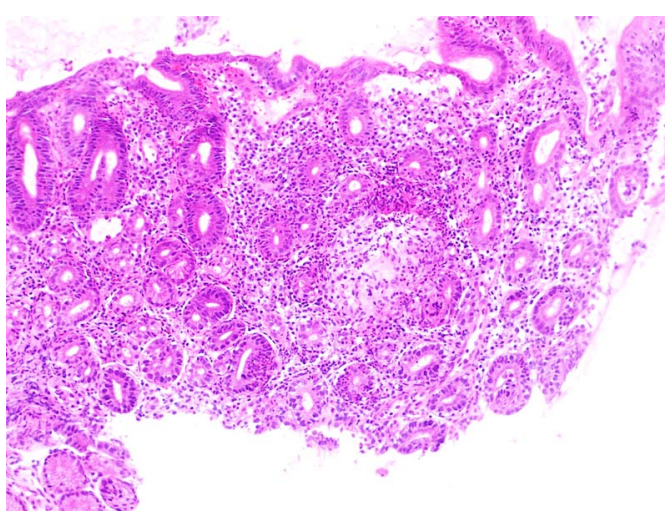

Figure 2 Biopsy specimen of the gastric erosion on the posterior wall of the stomach in the prepylorus region revealed an epithelioid-cell granuloma in the lamina propria $(\mathrm{H} \& \mathrm{E}$, original magnification $\times 100)$.

$H$ pylori infection or NSAIDs use as an oesophagogastroduodenoscopy indicator of CD.

\section{Learning points}

A consensus regarding the definition of what qualifies as significant gastric involvement in Crohn's disease (CD) is still lacking.

- Despite the controversy, granulomas not associated with ruptured crypts are usually considered specific histopathological findings of $C D$.

- Granulomas may be detected in gastric erosion biopsy specimens, therefore gastric erosions should be biopsied to confirm the diagnosis and extent of $C D$.

Contributors KT designed the study, performed the data collection and wrote the manuscript; KM and TK performed data collection and analysed the data; IM supervised the study and was involved in editing the manuscript.

Competing interests None.

Patient consent Obtained.

Provenance and peer review Not commissioned; externally peer reviewed.

\section{REFERENCES}

1 Hummel TZ, ten Kate FJ, Reitsma JB, et al. Additional value of upper $\mathrm{GI}$ tract endoscopy in the diagnostic assessment of childhood IBD. J Pediatr Gastroenterol Nutr 2012;54:753-7.

2 Annunziata ML, Caviglia R, Papparella LG, et al. Upper gastrointestinal involvement of Crohn's disease: a prospective study on the role of upper endoscopy in the diagnostic work-up. Dig Dis Sci 2012;57:1618-23.

3 Magro F, Langner C, Driessen A, et al. European consensus on the histopathology of inflammatory bowel disease. J Crohn's Colitis 2013;7:827-51. 
Copyright 2014 BMJ Publishing Group. All rights reserved. For permission to reuse any of this content visit http://group.bmj.com/group/rights-licensing/permissions.

BMJ Case Report Fellows may re-use this article for personal use and teaching without any further permission.

Become a Fellow of BMJ Case Reports today and you can:

- Submit as many cases as you like

- Enjoy fast sympathetic peer review and rapid publication of accepted articles

- Access all the published articles

- Re-use any of the published material for personal use and teaching without further permission

For information on Institutional Fellowships contact consortiasales@bmjgroup.com

Visit casereports.bmj.com for more articles like this and to become a Fellow 